\title{
INTRA INDUSTRY TRADE, FISCAL POLICY AND TERMS OF TRADE OF PAKISTAN: A LONG RUN ANALYSIS USING ARDL TECHNIQUE
}

\author{
FURRUKH BASHIR \\ Lecturer, Department of Economics, \\ The Islamia University of Bahawalpur, Pakistan \\ Bahawalnagar Campus. \\ Email: farrukh.bashir@iub.edu.pk \\ FAREEHA ANDLEEB \\ M. Sc. Scholar of Economics, \\ The Islamia University of Bahawalpur, Pakistan \\ Bahawalnagar Campus.

\section{RAHAT FATIMA} \\ M. Sc. Scholar of Economics, \\ The Islamia University of Bahawalpur, Pakistan \\ Bahawalnagar Campus.
}

\begin{abstract}
This study investigates long run relationship between Intra Industry Trade, fiscal policy and Terms of Trade of Pakistan. Considering the intention, time series data having time span from 1972 to 2014 is chosen. Data is collected through various sources like World Development Indicators, Handbook of Statistics on Pakistan Economy (2010) and Economic Survey of Pakistan (2014 - 15). After observing mixed stationary results of the variables [I(0), I(1)] using Augmented Dickey Fuller test, autoregressive and distributed lag model technique is applied for the analysis. For estimating elasticities of terms of trade with respect to the variables, log - log form of the model is utilized. The study reveals Intra Industry Trade, Real Gross Capital Formation and Real Government Expenditure as significant causes of improving Terms of Trade of Pakistan. On the other side, Terms of Trade of Pakistan is deteriorated due to real Gross Domestic Product and Real Foreign Direct Investment.
\end{abstract}

Keywords: Intra Industry Trade, Real gross domestic product, real foreign direct investment, real government expenditure, Real Gross Capital Formation, Autoregressive and Distributed Lag Model.

JEL Classification Codes: C12, C22, C87, D24, L16, L66, O23, Z38 


\section{INTRODUCTION}

Intra Industry Trade is considered to be an important factor for Terms of Trade of the economies. Production of differentiated goods may be beneficial in many terms like it reduces the monopoly power of existing firms, it opens the avenues for consumers to make rational decisions by expanding their choices of goods and services, it also creates new employment opportunities for skilled, semi-skilled, unskilled or technical labor, trade volume may also be expanded, etc. In other words, Intra Industry Trade may significantly affect Terms of Trade of any nation.

This study extends the previous knowledge base in multiple dimensions. Previously, Capital, nonfuel primary commodities, income, real wage, growth rate, relative market potential trade, per capita GDP, real exchange rate, trade openness, export, unemployment were noticed to have any influence on Terms of Trade in the economies. In this study, more attention is given to Intra Industry Trade and Term of Trade in Pakistan. Ordinary Least Square method and Generalized Method of Moments approaches were exercised for analysis purpose. Here, Augmented Dickey Fuller - Unit root test is used for examining stationary of variables and Autoregressive and Distributed lag model is employed as estimation technique carrying time series data up to 2014 - 15. In Pakistan, terms of trade were higher in 1974 and suddenly it declined during 1975 to 1977 . Then continuous declining trend had been seen in figure 1 till 2014.

\section{Figure 1: Terms of Trade}

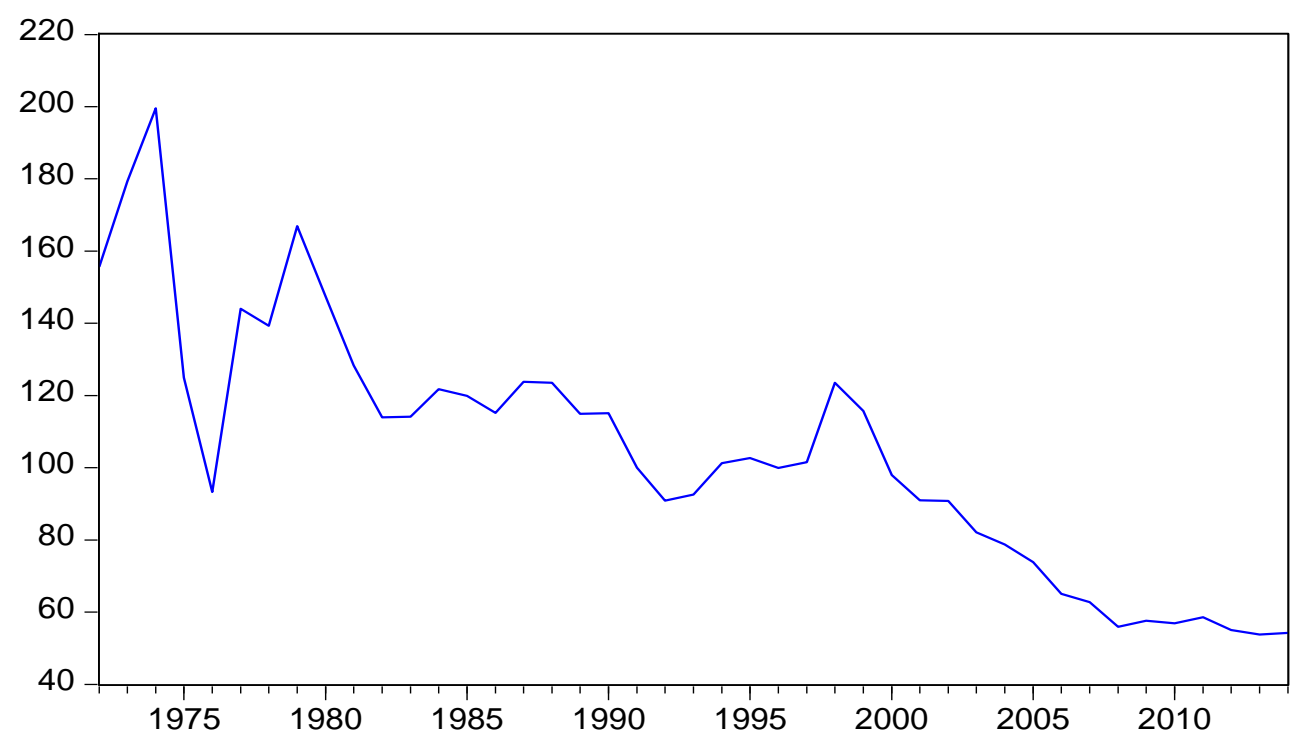


The situation of Intra Industry Trade of Pakistan may be analyzed through figure 2 which shows different ambiguous trend. From 1972 to 1985, production of differentiated goods was declined showing fall in Intra Industry Trade. After 1985, there was increase in production of differentiated goods in Pakistan and it was remained till 2003. After 2004, continuous fall in Intra Industry Trade may be analyzed till 2008 and then again this situation is changed.

\section{Figure 2: Intra Industry Trade}

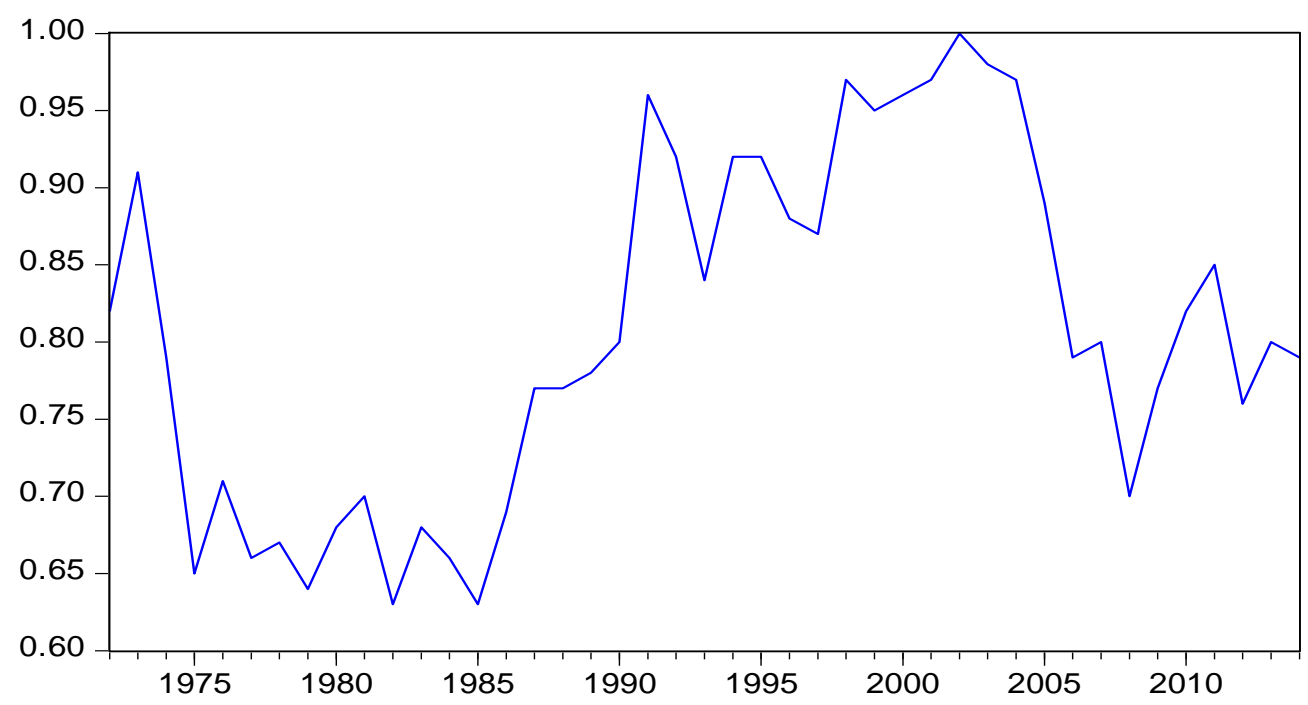

Analyzing figure 3, positive trend is seen in real government expenditure during 1972 to 2014.

\section{Figure 3: Real Government Expenditure}

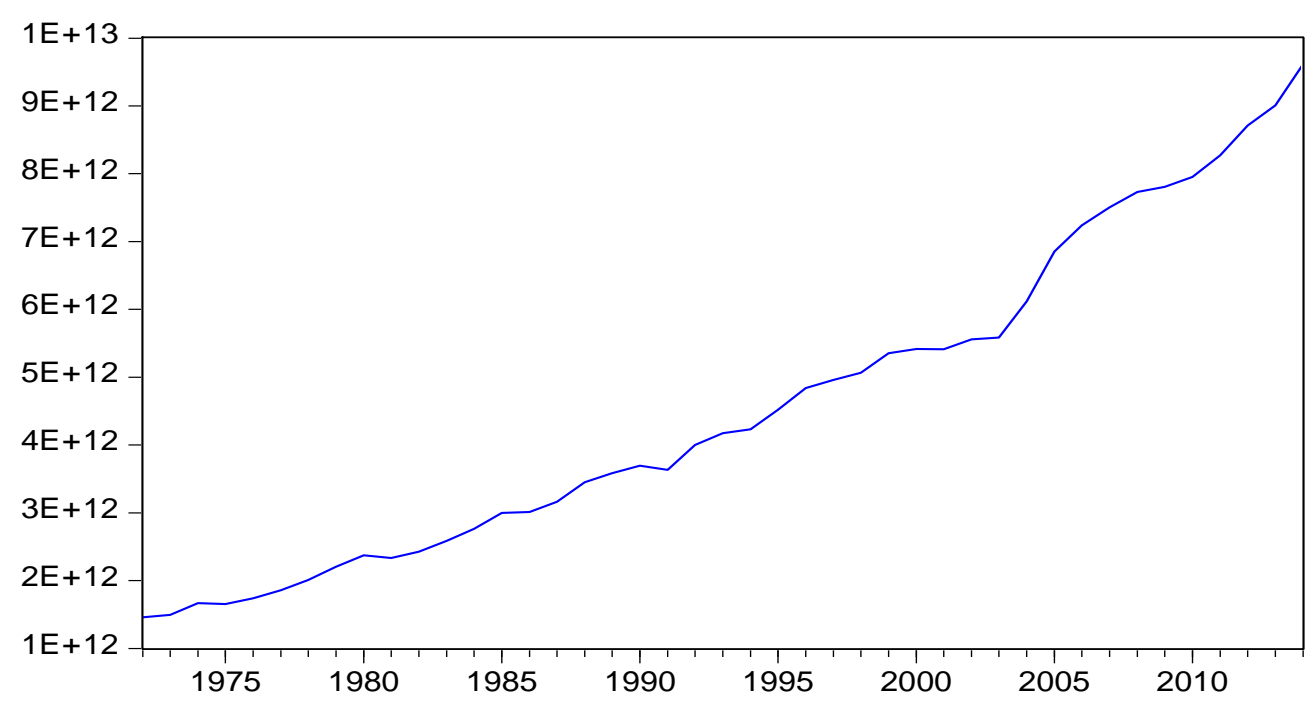


The objective of the study is to analyze the influence of Intra Industry trade and Fiscal Policy on Terms of Trade of Pakistan. Apart from Introduction in first section, this study gives summary of previous literature in section 2, section 3 is about data and methodological issues, section 4 discusses econometric results and concluding remarks with policy recommendations are provided in section 5 .

\section{REVIEW OF THE LITERATURE}

A number of researchers conducted studies to consider the determinants of terms of trade. This section presents the brief summary of related literature conducted at national and international levels.

Kravis and Lipsey (1981) analyzed terms of trade for exports of manufactured goods in developed countries. It was indicated that the price of manufactured goods exported by developed countries to developing countries raised by 75 percent over the twenty years. There was decline in terms of trade for the goods relative to primary products.

Evans (1987) examined the long run determinants of Terms of Trade. In this study, the researcher used data from 1953 to 1983. The study found positive relationship of capital, agriculture total factor productivity with Terms of Trade.

Grilli and Yang (1988) studied Term of Trade of developing countries. The study utilized time series annual data from 1900 to 1986 and results are estimated using the Ordinary Least Square method. Nonfuel primary commodities were negatively related and tropical beverages were positively associated with terms of trade.

Sarkar and Brighton (1991) investigated terms of trade. Using time series data from 1965 to 1985, estimated results were found by fitting exponential trend equation. A positive relationship was established between relative and absolute income of terms of trade.

Ziesemer (1994) evaluated the economic development and endogenous terms of trade determination. The researcher exhibited positive association among indicator of economic development and terms of trade. Optimistic association was analyzed among per capita income, real wages employment, capital, labor and terms of trade. Pessimistic association was realized among growth rate and terms of trade. 
Maizels et al. (2000) considered the manufactured terms of trade of developing countries with United States for time period from 1981 to 1997. The net barter terms of trade of developing countries showed deterioration in the first half of the 1980 while manufactured terms of trade of developing countries were deteriorating terms of trade in whole time period.

Debaere and Lee (2003) explored real side determinates of countries' terms of trade. In the study, authors considered panel data from 1973 to 1980 and estimated the results using the GMM. Country output deteriorated terms of trade. However, relative market potential and per capita GDP improved term of trade.

Dungey (2004) identified terms of trade by applying time series annual data from 1967 to 1998 and estimated the results using Generalized Method of Moments. Positive relationship was found among terms of trade and export while negative association was established between real exchange rate, import and term of trade. Kaplinsky (2006) evaluated price differentiation with commodities and within manufacturing as deteriorating terms of trade of commodity producers.

Carter and Zhu (2009) discovered terms of trade in china using time series data from 1978 to 2005. It was concluded that trade pattern had positive impact on the domestic terms of trade while trade openness is a cause of improving terms of trade.

Lee and Kim (2011) searched determinants of Korean terms of trade using panel data from 2000 to 2009. Employing generalized method of moments, Increase in the lagged term of trade relative to market potential or relative to per capita income was improving terms of trade. Although, negative association was discovered between relative output, manufactured goods in exports and terms of trade.

Cederlof (2012) determined terms of trade using Panel data from 1980 to 2010. Utilizing Ordinary Least Square estimation approach, deterioration in terms of trade was found due to weak labor unions and abundance of labor.

Otero and Iregui (2013) checked terms of trade between primary commodities and manufactures using panel data from 1900 to 2010. A long run negative trend of primary and manufactured commodities was seen for terms of trade. 
Araujo (2013) looked terms of trade for time series data from 1970 to1999. There was improvement in terms of trade due to markup prices of industrialization and deterioration due to high rate of technological progress.

Chakraborty (2012) inquired terms of trade of developed countries. Time series data is chosen from 1975 to 2005. Exports were concluded significant cause of improving terms of trade while growth rate was deteriorating terms of trade.

Abri and Gani (2014) investigated terms of trade using Panel data from 1980 2010 and generalized method of moments was utilized as an estimation technique. Terms of trade was improved by savings rate while it was deteriorated due to real gross domestic product.

\section{DATA AND METHODOLOGY}

This section discusses Data Description, Model Specification, and Methodology of Autoregressive and distributed lag model in long run and short run.

\section{A. DATA DESCRIPTION}

The present study collects time series data over the period from 1972 to 2014 in case of Pakistan. Reliable data sources are followed like data about terms of trade is collected from 50 Years of Pakistan in Statistics, Handbook of Statistics on Pakistan Economy 2010 and Economic Survey of Pakistan. Data of Real gross domestic product, foreign direct investment, intra industry trade and real gross capital formation are collected from Economic Survey of Pakistan (2014- 2015) and World Development Indicator.

\section{B. MODEL SPECIFICATION}

Considering objective of the study that is to analyze long run relationship between Intra Industry Trade, Fiscal Policy and Terms of trade, the following Econometric Model is specified.

$$
L T O T=\beta_{0}+\beta_{1} L I I T+\beta_{2} L R G D+\beta_{3} L R G C F+\beta_{4} L R G X+\beta_{5} L R F D+u_{i}
$$

Where, in the above equation,

$\begin{array}{lll}\text { LTOT } & = & \text { Term of trade } \\ \text { LIIT } & = & \text { Intra Industry Trade }\end{array}$




$\begin{array}{lll}\text { LRGD } & = & \text { Real Gross domestics product } \\ \text { LRGCF } & = & \text { Real Gross Capital Formation } \\ \text { LRGX } & = & \text { Real Government Expenditure } \\ \text { LRFD } & = & \text { Real Foreign direct investment } \\ \beta_{0} & = & \text { Intercept } \\ \beta_{i}^{\prime} \text { S } & = & \text { Coefficients } \\ u_{i} & = & \text { Error Term }\end{array}$

The variable description, unit of measurement and expected relationships are provided in table 1.

Table 1: Unit of Measurement and Expected Relationship

\begin{tabular}{cccc}
\hline Variable & Description & $\begin{array}{c}\text { Unit of } \\
\text { Measurement }\end{array}$ & $\begin{array}{c}\text { Expected } \\
\text { Relationship }\end{array}$ \\
\hline LTOT & $\begin{array}{l}\text { Terms of trade } \\
\text { TOT } \\
=\frac{\text { Price Index of Exportable Commodity }}{\text { Price Index of Importable Commodity }}\end{array}$ & Index (base year 2000) \\
\hline LIIT & Intra Industry Trade & Index & Positive \\
\hline LRGD & IIT $=1-\frac{|\mathrm{X}-\mathrm{M}|}{(\mathrm{X}+\mathrm{M})}$ & $\begin{array}{c}\text { Pakistani } \\
\text { Rupees }\end{array}$ & Negative \\
\hline LRGCF & Real Gross Domestics Product & Pakistani Rupee & Positive \\
\hline LRGX & Real Government Expenditure & Pakistani Rupee & Positive \\
\hline LRFD & Real Foreign Direct Investment & Pakistani Rupee & Negative \\
\hline
\end{tabular}

\section{METHODOLOGICAL DISCUSSION}

\section{AUGMENTED DICKEY FULLER TEST}

A variable is said to be stationary if its mean, variance and covariance stay constant no matter at which point we determine them. A number of tests are used to check unit root problem. If error terms are uncorrelated than Dickey Fuller test is applicable. If error terms are correlated then Dickey Fuller test is inapplicable. Augmented Dickey Fuller test is taken care of this problem by augmenting the equation of Dickey Fuller test by adding the lagged values of dependent variable. To test the unit root property we employed ADF test as follows; 
Without Drift and Trend:

$$
\Delta Y_{t}=\delta Y_{t-1}+\alpha_{i} \sum_{i=1}^{m} \Delta Y_{t-i}+u_{i}
$$

With Drift and no Trend:

$$
\Delta Y_{t}=\beta_{1}+\delta Y_{t-1}+\alpha_{i} \sum_{i=1}^{m} \Delta Y_{t-i}+u_{i}
$$

With Drift and Trend:

$$
\Delta Y_{t}=\beta_{1}+\beta_{2} t+\delta Y_{t-1}+\alpha_{i} \sum_{i=1}^{m} \Delta Y_{t-i}+u_{i}
$$

\section{ARDL BOUND TEST FOR TERMS OF TRADE}

To examine influence of Intra Industry Trade on Terms of Trade, Autoregressive and Distributed Lag model is employed. Engel granger (1987) and Johansen $(1998,1991)$ discovered eminent methods. Johansen Cointegration technique is used in multivariate model when all variables are integrated of order 1 or 1(1). When some variables are stationary at level or $1(0)$, and some at 1 st difference or $1(1)$, then ARDL test technique is the most suitable. Autoregressive and distributed lag (ARDL) is developed by Pesaran and Shin (1998) and Pesaran et al. (1999) that does not need any pretesting of variable. ARDL test is also used for longrun and short run result.

Two steps action are pursued to estimate long run relationship with variable. A beginning analysis is to check existence of long run association that may be established by the following unrestricted error modification regression for models at suitable lag length $(u)$.

$$
\begin{aligned}
\Delta L T O T= & {\left[\delta_{\circ}+\sum_{j=0}^{u} \delta_{2 j} \Delta L I I T_{t-j}+\sum_{j=0}^{u} \delta_{3 j} \Delta L R G D_{t-j}+\sum_{j=0}^{u} \delta_{4 j} \Delta L R G C F_{t-j}\right.} \\
& +\sum_{j=0}^{u} \delta_{5 j} \Delta L R G X_{t-j}+\sum_{j=0}^{u} \delta_{6 j} \Delta L R F D_{t-j}+\alpha_{0} L T O T_{t-1}+\alpha_{1} L I I T T_{t-1} \\
& \left.+\alpha_{2} L R G D_{t-1}+\alpha_{3} L R G C F_{t-1}+\alpha_{4} L R G X_{t-1}+\alpha_{5} L R F D_{t-1}+\omega_{1 t}\right]
\end{aligned}
$$


The Wald test or F-statistics is used for to check long run co integrating relationship. The null hypothesis for co-integration along variable in equation is given below:

$$
\left[H_{0}: a_{0}=a_{1}=a_{2}=a_{3}=a_{4}=a_{5}=0\right]
$$

The $\mathrm{F}$ statistic in this methodology construct with 2 sets critical values provided by the Pesaran et al. (2001) to conduct bound test. If calculated value of F-statistics is greater than the upper bound critical value then null hypothesis of no co-integration may be rejected. If calculated $F$ statistics value is less than upper bound then null hypothesis cannot be rejected. If value of F-Statistics fall inside the lower and upper bound then cointegration does not exist. Variables that have order of integrated 1(2) are dropped from the study for reliable result because in the presence of 1(2) long run relationship may not exist.

\section{TERMS OF TRADE IN LONG RUN}

Following is the long run model estimated using $\operatorname{ARDL}(m, n, 0, p, q, r)$ models where d's are long run elasticities.

$$
\begin{aligned}
\Delta \text { LTOT }= & {\left[\mathrm{d}_{0}+\sum_{\mathrm{j}=1}^{\mathrm{m}} \mathrm{d}_{1 \mathrm{j}} \Delta \text { LTOT }_{\mathrm{t}-\mathrm{j}}+\sum_{\mathrm{j}=0}^{\mathrm{n}} \mathrm{d}_{2 \mathrm{j}} \Delta \text { LIIT }_{\mathrm{t}-\mathrm{j}}+\sum_{\mathrm{j}=0}^{\mathrm{o}} \mathrm{d}_{3 \mathrm{j}} \Delta \text { LRGD }_{\mathrm{t}-\mathrm{j}}\right.} \\
& \left.+\sum_{\mathrm{j}=0}^{\mathrm{p}} \mathrm{d}_{4 \mathrm{j}} \Delta \mathrm{LRGCF}_{\mathrm{t}-\mathrm{j}}+\sum_{\mathrm{j}=0}^{\mathrm{q}} \mathrm{d}_{5 \mathrm{j}} \Delta \mathrm{LRGX}_{\mathrm{t}-\mathrm{j}}+\sum_{\mathrm{j}=0}^{\mathrm{r}} \mathrm{d}_{6 \mathrm{j}} \Delta \mathrm{LRFD}_{\mathrm{t}-\mathrm{j}}+\mathrm{v}_{1}\right]
\end{aligned}
$$

\section{TERMS OF TRADE IN SHORT RUN}

Short run coefficients are examined by constructing an error correction model using following forms:

$$
\begin{aligned}
\Delta \text { LTOT } & {\left[\mathrm{g}_{0}+\sum_{\mathrm{j}=1}^{\mathrm{m}} \mathrm{g}_{1 \mathrm{j}} \Delta \text { LTOT }_{\mathrm{t}-\mathrm{j}}+\sum_{\mathrm{j}=0}^{\mathrm{n}} \mathrm{g}_{2 \mathrm{j}} \Delta \mathrm{LIIT}_{\mathrm{t}-\mathrm{j}}+\sum_{\mathrm{j}=0}^{\mathrm{o}} \mathrm{g}_{3 \mathrm{j}} \Delta \mathrm{LRGD}_{\mathrm{t}-\mathrm{j}}\right.} \\
& +\sum_{\mathrm{j}=0}^{\mathrm{p}} \mathrm{g}_{4 \mathrm{j}} \Delta \mathrm{LRGCF}_{\mathrm{t}-\mathrm{j}}+\sum_{\mathrm{j}=0}^{\mathrm{q}} \mathrm{g}_{5 \mathrm{j}} \Delta \mathrm{LRGX}_{\mathrm{t}-\mathrm{j}}+\sum_{\mathrm{j}=0}^{\mathrm{r}} \mathrm{g}_{6 \mathrm{j}} \Delta \mathrm{LRFD}_{\mathrm{t}-\mathrm{j}} \\
& \left.+\Psi_{1} \mathrm{ECM}_{\mathrm{t}-1}+\varepsilon_{1_{\mathrm{t}}}\right]
\end{aligned}
$$


In short run equation, $\Delta$ is first difference operator, g's are short run elasticities, $\psi$ is speed of adjustment term if negative then shows convergence towards long run equilibrium, and ECM is error correction mechanism.

\section{RESULTS AND DISCUSSIONS}

\section{A. DESCRIPTIVE ANALYSIS}

Table 2 provides descriptive statistics of the variables used in the study. On the average Terms of trade, Intra Industry Trade, Real GDP, Real Gross capital formation, Real government expenditure and real FDI is 104.7, 0.81, 5080 Billion rupees, 986 billion rupees, 4560 billion rupees and 8.5 billion rupees respectively in Pakistan during 1972 to 2014. Terms of trade, Intra Industry Trade, real GDP, real government expenditure and real FDI are positively skewed while real gross capital formation is negatively skewed. Discussing distribution of variables, Intra Industry Trade, real GDP, real gross capital formation and real government expenditure are Platykurtic. Terms of trade is having Mesokurtic distribution while real GDI is having Leptokurtic distribution. Terms of trade of Pakistan lies between 53.8 and 199.5 during period of research. Intra Industry Trade and real government expenditure lie between 0.63 and 1; 1460 and 9620 billion rupees in that order.

Table 2: Descriptive Analysis

\begin{tabular}{lcccccc}
\hline Variables & TOT & IIT & RGD(B) & RGCF(B) & RGX(B) & RFD(B) \\
\hline Mean & 104.7 & 0.81 & 5080 & 986 & 4560 & 8.5 \\
\hline Median & 101.5 & 0.80 & 4750 & 1080 & 4170 & 3.36 \\
\hline Maximum & 199.5 & 1 & 10700 & 1700 & 9620 & 55.9 \\
\hline Minimum & 53.8 & 0.63 & 144000 & 3444 & 1460 & 0.04 \\
\hline Std. Dev. & 35.12 & 0.1 & 2770 & 408 & 2350 & 13.4 \\
\hline Skewness & 0.47 & 0.06 & 0.42 & -0.06 & 0.51 & 2.42 \\
\hline Kurtosis & 3.02 & 1.78 & 2 & 1.88 & 2.12 & 8.35 \\
\hline
\end{tabular}

\section{B. UNIT ROOT RESULTS}

The results of unit root test are reported in table 3. This table provides the evidence that terms of trade and real FDI are stationary at level and real government expenditure, real GDP, Intra Industry Trade, and real gross capital formation are stationary 
at their $1^{\text {st }}$ differences. This may lead us to apply Autoregressive and distributed lag model for long run coefficients.

Table 3: Augmented dickey fuller Test

\begin{tabular}{|c|c|c|c|c|c|}
\hline Variable & $\begin{array}{l}\text { Test for } \\
\text { Unit } \\
\text { Root in }\end{array}$ & $\begin{array}{c}\text { Include in } \\
\text { Test } \\
\text { Equation }\end{array}$ & $\begin{array}{c}\text { Test } \\
\text { Statistics }\end{array}$ & Probability & Result \\
\hline \multirow{2}{*}{ Terms of Trade } & \multirow{2}{*}{ Level } & Intercept & -1.022486 & 0.7366 & \multirow{2}{*}{$1(0)$} \\
\hline & & Trend & -3.254095 & 0.0881 & \\
\hline \multirow{3}{*}{\begin{tabular}{l}
\multicolumn{1}{c}{ Real } \\
Government \\
expenditure
\end{tabular}} & \multirow{2}{*}{ Level } & Intercept & -1.125013 & 0.6971 & \multirow{3}{*}{$1(1)$} \\
\hline & & Trend & -2.839568 & 0.1922 & \\
\hline & $\begin{array}{l}1^{\text {st }} \\
\text { difference }\end{array}$ & Intercept & -6.247858 & 0.0000 & \\
\hline \multirow{3}{*}{$\begin{array}{l}\text { Real Gross } \\
\text { Capital } \\
\text { Formation }\end{array}$} & \multirow{2}{*}{ Level } & Intercept & -2.219420 & 0.2027 & \multirow{3}{*}{$1(1)$} \\
\hline & & Trend & -0.756665 & 0.9616 & \\
\hline & $\begin{array}{l}1^{\text {st }} \\
\text { difference }\end{array}$ & Intercept & -5.754509 & 0.0000 & \\
\hline \multirow{3}{*}{ Real GDP } & \multirow{2}{*}{ Level } & Intercept & -1.78329 & 0.3804 & \multirow{3}{*}{$1(1)$} \\
\hline & & Trend & -1.013128 & 0.93 & \\
\hline & $\begin{array}{l}1^{\text {st }} \\
\text { difference }\end{array}$ & Intercept & -4.310126 & 0.0014 & \\
\hline \multirow{3}{*}{$\begin{array}{c}\text { Intra Industry } \\
\text { Trade }\end{array}$} & \multirow{2}{*}{ Level } & Intercept & -1.845448 & 0.3541 & \multirow{3}{*}{$1(1)$} \\
\hline & & Trend & -2.146558 & 0.5058 & \\
\hline & $\begin{array}{l}1^{\text {st }} \\
\text { difference }\end{array}$ & Intercept & -7.347365 & 0.0000 & \\
\hline \multirow{2}{*}{$\begin{array}{l}\text { Real Foreign } \\
\text { Direct } \\
\text { Investment }\end{array}$} & \multirow{2}{*}{ Level } & Intercept & -1.26 & 0.63 & \multirow{2}{*}{$1(0)$} \\
\hline & & Trend & -3.47 & 0.05 & \\
\hline
\end{tabular}

\section{ECONOMETRIC ANALYSIS}

ARDL long run and short run results are presented in table 4. This table shows five columns; in which first column provides names of the variables, second column is about coefficients, standard errors are given in third column, forth column reports $t$ statistics, probability values of each variable is mentioned in fifth column. ARDL bound test results clarifies that there exists long run relationship between terms of trade and explanatory variables included in the model because F - statistics (3.06) is significantly greater than upper bound value $(I(1))$ that 3 .

Intra Industry Trade is found to be cause of improving Terms of Trade of Pakistan. The long run coefficient is 1.24 that is significant at 1 percent level of significance. If Pakistan produces and exports differentiated goods to reduce competition among goods of same nature so it will raise export prices causing improvement in terms of trade of 
Pakistan. On the average, one percent higher production of differentiated goods may improve terms of trade of Pakistan by 1.24 percent. Long run elasticity of terms of trade with respect to Intra Industry trade is 1.24 . In the short run, the study finds same behavior of Intra Industry trade with terms of trade of Pakistan. In the short run, one percent higher intra industry trade may be cause of improving terms of trade by 1.25 and 0.33 percent on the average with statistically significant. Similar findings are concluded by Cederlof (2012) and Chakraborty (2012).

Real gross domestic product is appeared to be a cause of deterioration in terms of trade of Pakistan with significant long run coefficient having value -5.73 . Higher production of goods and services domestically may lead supply greater than demand that may be a cause of lower price level or deflation. Deflation of the economy may be significant cause of higher trade at lower export prices. In turn, lower export prices may deteriorate terms of trade of Pakistan. The long run elasticity of terms of trade with respect to real gross domestic product is -5.73 . It signifies 5.73 percent deterioration in terms of trade due to one percent higher real gross domestic product of Pakistan on the average in the long run. These results are similar to findings of Chakraborty (2012) and Ziesemer (1994).

Real gross capital formation is used as proxy of investment in the study. Higher investment may lead to diversification in business and may produce mechanized tools as well. More diversification in goods ultimately charge higher export prices as well which may improve terms of trade of Pakistan. Econometrically, the study reveals positive sign of real gross capital formation in long run results that is significant at 1 percent level. The long run coefficient is 1.77 indicating improvement in terms of trade by 1.77 percent due to one percent higher investment on the average. The long run elasticity of terms of trade with respect to real gross capital formation is calculated as 1.77 . Similar results are exhibited in the short run with coefficient value of 1.05 having significant probability value. These results are reconciliated with findings of Evans (1987), Ziesemer (1994) and Lee and Kim (2011).

Fiscal policy of Pakistan is hypothesized as improving terms of trade of Pakistan. Real Government Expenditure are taken as fiscal policy in the analysis and econometric results conclude positive sign attached with this variable implying improvement in terms of trade by about 4.17 percent due to one percent of higher real government expenditure in Pakistan. Statistically, this value is significant at 1 percent level. In the short run, the 
coefficient attached with government expenditure is also positive. It may be justified as when government develops infrastructure for industries so new investment may take place on production of diversified range of product that will motivate the producers to charge reasonable price. It may be a cause of higher export price causing improvement in terms of trade of Pakistan in the short run as well as in the long run. Long run fiscal policy of terms of trade is calculated as 4.17 and short run elasticity of terms of trade with respect to government expenditure is 2.89 .

Deterioration in terms of trade is indicated in long run results due to real foreign direct investment in Pakistan but coefficient value is statistically not significant in the long run as well as in the short run. Insignificant results may suggest no influence on terms of trade eliminates its value for future forecasting. Co-integrating equation term is significantly different from zero at 1 percent level of significance having coefficient value -0.67 suggesting that economy will converge towards long run equilibrium if any disturbance occurs in the short run.

Table 4: Auto Regressive Distributed Lag

\begin{tabular}{lllll}
\hline \multicolumn{1}{c}{ Variable } & \multicolumn{1}{c}{ Coefficients } & \multicolumn{1}{c}{ Standard Error } & t-statistics & Probability \\
\hline LIIT & \multicolumn{4}{c}{ Long run Results } \\
\hline LRGD & 1.24 & 0.21 & 5.90 & 0.00 \\
\hline LRGCF & -5.73 & 1.20 & -4.76 & 0.00 \\
\hline LRGX & 1.77 & 0.45 & 3.86 & 0.00 \\
\hline LRFD & 4.17 & 1.02 & 4.07 & 0.00 \\
\hline CONSTANT & -0.08 & 0.05 & -1.53 & 0.13 \\
\hline & 2.99 & 5.01 & 0.58 & 0.56 \\
\hline D(LTOT(-1)) & 0.14 & 0.09 & 1.56 & 0.12 \\
\hline D(LIIT) & 1.25 & 0.20 & 6.23 & 0.00 \\
\hline D(LIIT (-1)) & 0.33 & 0.15 & 2.18 & 0.03 \\
\hline D(LRGD) & -4.02 & 0.78 & -5.09 & 0.00 \\
\hline D(LRGD(-1)) & 1.65 & 0.57 & 2.87 & 0.00 \\
\hline D(LRGCF) & 1.05 & 0.27 & 3.89 & 0.00 \\
\hline D(LRGX) & 2.89 & 0.43 & 6.63 & 0.00 \\
\hline D(LRFD) & -0.00 & 0.02 & -0.20 & 0.84 \\
\hline D(LRFD(-1) & -0.03 & 0.02 & -1.81 & 0.08 \\
\hline CointEQ(-1) & -0.67 & 0.12 & -5.56 & 0.00 \\
\hline & & Short run Results & \\
\hline
\end{tabular}

\section{ARDL bound test}

$\begin{array}{llll}\text { F statistics: } 3.06 & \text { Significance: } 10 \% & \text { I(0) Bound: } 2.08 & \text { I(1) Bound: } 3\end{array}$

Note: Dependent variable is Terms of trade 


\section{CONCLUSIONS AND POLICY IMPLICATIONS}

Intra Industry Trade and Fiscal Policy play an important role in Terms of Trade of any economy. Keeping in mind, the study focuses on the role of Intra Industry Trade and Fiscal Policy on Terms of Trade of Pakistan. Time series data is collected during the period from 1972 to 2014 through reliable sources like World Development Indicators, 50 years of Pakistan, Economic Survey of Pakistan $(2014$ - 15) and Handbook of Statistics on Pakistan Economy 2010.

Terms of Trade and Intra Industry Trade are indexes while real gross capital formation, real gross domestic product, real government expenditure and real foreign direct investment are taken in Pakistan rupees. For estimation of elasticities, log - log form of the equation is considered in the long run as well in the short run. For average values, descriptive statistics are calculated which shows Mean, Median, Maximum, Minimum, Standard Deviation, Skewness and Kurtosis of the variables used in study. Augmented Dickey Fuller test is utilized for examining stationary of variables while econometric results are estimated using Autoregressive and Distributed lag model along with ARDL Bound testing Approach.

Stationary results concludes that terms of trade and real foreign direct investment are stationary at level while Intra Industry trade, real gross domestic product, real gross capital formation and real government expenditure are stationary at their $1{ }^{\text {st }}$ differences that propose us to utilize ARDL test for econometric analysis. In the long run, Intra Industry Trade, real gross capital formation, real government expenditure are found to improve Terms of Trade of Pakistan while real gross domestic product is a cause of deterioration in Terms of Trade of Pakistan.

On the basis of results, the study suggests that product differentiation is the best tool for improving Terms of Trade of Pakistan which should be carried on in the future by the policy makers along with suitable fiscal policy framework. Infrastructural development is one of the important tools of industrialization and boosting up of Trade which may improve Terms of Trade as well and financing may be provided by real government expenditure and real gross capital formation. 


\section{References}

Al-Abri, A. S., \& Gani, A. (2014). National Saving and Terms-of-Trade: The HarbergerLaursen-Metzler Effect Revisited. Available at SSRN 2572968.

Araujo, R. (2013). Assessing the Dynamics of Terms of Trade in a Model of Cumulative Causation and Structural Change. MPRA paper 46019, 1-26.

Asteriou, D. (2005). Applied Econometrics: A modern approach using EViews and Microfit, Palgrave Macmilan.

Carter, C. A., \& Zhu, J. (2009). Trade Liberalization and Agricultural Terms of Trade in China: Price Scissors Revisited. In 2009 Conference, August 16-22, 2009, Beijing, China (No. 51636). International Association of Agricultural Economists.

Cederlöf, J. (2012). Are the Labor Market Conditions Causing the Terms of Trade to deteriorate? A statistical evaluation of the Prebisch-Singer hypothesis. 1 - 30.

Chakraborty, S. (2012). Manufacture Exports of the Developing Countries and their Terms of Trade vis-vis the Developed Countries: Is Industrialization of Developing Countries An "Escape Route" from Prebisch Singer Hypothesis? 1 - 39.

Debaere, P., \& Lee, H. (2003). The Real-Side Determinants of Countries' terms of trade A Panel Data Analysis. Mimeo, University of Texas, Austin.

Dungey. M. (2004). Identifying Terms of Trade Effect in Real Exchange Rate Movements: Evidence from Asia. Journal of Asian Economics, 15,217-235.

Engle, R. F. and Granger, C. W. J. (1987). Co-integration and Error Correction: Representation, Estimation, and Testing. Econometrica, 55(2), 251 - 276.

Evans, D. (1987). The Long run Determinants of North-South Terms of Trade and Some Recent Empirical Evidence. Journal of World development, 15(5), 657-671.

Govt. of Pakistan (2000). 50 years of Pakistan in Statistics, Federal Bureau of Statistics, Statistical Division.

Govt. of Pakistan (2011). Handbook of Statistics on Pakistan Economy 2010, State bank of Pakistan.

Govt. of Pakistan (2014). Pakistan Economic Survey, Federal Bureau of Statistics, Statistical Division.

Grilli, E. R., \& Yang, M. C. (1988). Primary commodity prices, manufactured goods prices, and the terms of trade of developing countries: what the long run shows. The World Bank Economic Review, 2(1), 1 - 47.

Gujarati, D. N. and Porter, D. C. (2009). Basic Econometrics, $5^{\text {th }}$ Edition.

Johansen, S. (1988). Statistical analysis of co-integrating vectors. Journal of Economic Dynamics and Control, 12, 231 - 254.

Johansen, S. (1991). Estimation and Hypothesis Testing of Cointegration Vectors in Gaussian Vector Autoregressive models. Econometrica, 59(6), 1551 - 1580.

Kaplinsky, R. (2006). Revisiting the Revisited Terms of Trade: Will China Make a Difference? Journal of World Development, 34(6), 981-995. 
Lee, H. and Kim, H. K. (2011). The Determinates of Korea's Terms of Trade: The RealSide Approach. Journal of East Asian Economic Integration, 15(4), 21-41.

Maizels, A., Berge, K., Crowe, T., \& Palaskas, T. B. (2000). The manufactures terms of trade of developing countries with the United States, 1981-97. QEH Working Paper 36. Oxford University, Queen Elizabeth House, Oxford.

Otero, J., \& Iregui, A. M. (2011). The Long-Run Behaviour of the Terms of Trade between Primary Commodities and Manufactures: A Panel Data Approach. No. UNUWIDER Research Paper WP2011/71, 2 - 30.

Pesaran, H. M. and Shin, Y. (1999). Autoregressive Distributed Lag Modelling approach to Cointegration Analysis. Econometrics and Economic Theory in the 20 $0^{\text {th }}$ Century: The Ragnar Frisch Centennial Symposium (Cambridge: Cambridge University Press).

Pesaran, M. H., Shin, Y. and Smith, R. J. (1999). Structural analysis of vector error correction models with I(1) exogenous variables. Department of Applied Economics Working Paper, University of Cambridge.

Pesaran, M. H., Shin, Y. and Smith, R. J. (2001). Bound testing approaches to the analysis of level relationships. Journal of Applied Econometrics, 16, 289 - 326.

Sarkar, P. and Singer, H. W. (1991). Manufactured Exports of Developing Countries and Their Terms of Trade Since 1965. Journal of World Development, 19(4), 333-340.

World Bank, (2014). World Development Indicators. World Bank, Washington, DC.

Ziesemer, T. H. (1994). Economic development and endogenous terms-of-trade determination: review and reinterpretation of the Prebisch-Singer thesis. 1-17. 